\title{
Seasonal Variation of Soil Chemical Characteristics at Akwuke Long Wall Underground Mined Site, Nigeria
}

\author{
*1OGBONNA, PC; ${ }^{1}$ NZEGBULE, EC; ${ }^{2}$ OKORIE, PE \\ ${ }^{I}$ Department of Environmental Management and Toxicology, Michael Okpara University of Agriculture, PMB 7267 Umuahia, Abia State, \\ Nigeria \\ ${ }^{2}$ Department of Forestry and Environmental Management, Michael Okpara University of Agriculture, Umudike P.M.B. 7267 Umuahia, \\ Abia State, Nigeria \\ *Corresponding Author Email: ogbonna_princewill@yahoo.com; +2348063402809
}

\begin{abstract}
The on-going action and plan to revive old coal mines in Nigeria necessitated a study on the soil chemical characteristics at abandoned coal mine in Akwuke, Enugu State, Nigeria. A single factor experiment was conducted in a randomized complete block design (RCBD) with three replications to obtain information on soil status of Akwuke mined site. Soil samples were collected randomly from ten different sampling points at 0-10,10-20, and 20-30 cm soil depth in four cardinal points at north $(\mathrm{N})$, south $(\mathrm{S})$, east $(\mathrm{E})$, west $(\mathrm{W})$, and at the center (c) of crest, middle slope, and valley of Akwuke mined site. The samples were analyzed for heavy metals, macronutrient, soil $\mathrm{pH}$, and organic matter content. Soil $\mathrm{pH}$ (4.29-6.14) in wet season is higher than 4.14-5.58 in dry season at Akwuke mine site. The values of N, P, K, Ca, and $\mathrm{Mg}$ in soil at Akwuke mine were higher in dry season than in wet season. The highest soil organic matter content $(0.96 \pm 0.04 \%)$ at Akwuke mine is obtained in dry season at $0-10 \mathrm{~cm}$ valley. The concentrations of $\mathrm{Ni}, \mathrm{Pb}$, and $\mathrm{Cd}$ in soil at mined site ranged from $4.15 \pm 0.07$ to $19.81 \pm 1.29,6.11 \pm 0.13$ to $21.10 \pm 0.85$, and $0.01 \pm 0.00$ to $3.06 \pm 0.08 \mathrm{mg} / \mathrm{kg}$. $\mathrm{Mg}$ $(89.60 \pm 1.41$ to $251.9 \pm 1.41 \mathrm{cmol} / \mathrm{kg})$. Cd and $\mathrm{Ni}$ in soil at the mined site was higher than their allowable limits in Austria, Germany, France, Netherlands, Sweden, and United Kingdom. The high concentrations of these metals $(\mathrm{Cd}$ and $\mathrm{Ni})$ in soils could expose both animals and local inhabitants to high levels of $\mathrm{Cd}$ and $\mathrm{Ni}$, thus, posing a serious health risks to the local people.
\end{abstract}

\section{DOI: https://dx.doi.org/10.4314/jasem.v22i8.26}

Copyright: Copyright $@ 2018$ Ogbonna et al. This is an open access article distributed under the Creative Commons Attribution License (CCL), which permits unrestricted use, distribution, and reproduction in any medium, provided the original work is properly cited.

Dates: Received: 28 June 2018; Revised: 30 July: 2018; Accepted: 27 August 2018

Key words: Seasonal variation, Akwuke mine, coal, chemical characteristics

Coal is a hard black mineral found in coalface where it is cut out of the rock. It is the world's most abundant, most accessible and versatile source of fossil energy which was brought to the fore-front of the global energy scene by the industrial revolution of the 10th century (Akinbami et al., 2001). The use of coal energy especially for cooking in Nigeria will increase beyond the present level as a result of (a) high poverty rate and increasing decimation of secondary and artificial forest plantations for timber production and construction of household furniture such as upholstery seats, tables, doors among others, (b) the use of coal as source of energy for production of cement in cement industries, and (c) the high rate of pipeline vandalization and oil spillage resulting to extensive burning of vegetation and destruction of soil seed banks cum serious decline in soil fertility, thus, leading to poor regeneration of plant community.

Coal contain heavy metals, hence mining processes such as blasting, excavation, processing and transportation of coal releases metals into the environment and plants growing on such metal contaminated sites will absorb these metals. Herbivorous animals largely depends on plants for food and as cover from predators, and most animals in the wild scratch their bodies against plants as a way of soothing their itching skin. Animal exposure to metals will constitute serious health risk. Since man also relied heavily on plants for food, medicine and shelter, studies on soil metal-contaminated sites and their peripheries are essential for accurate assessment of metal toxicity of soils in relation to possible toxic impacts on human health (Ogbonna et al., 2012).

Since 1916 when coal mining commenced in Nigeria, it has become a major land-use particularly in south eastern Nigeria where many natives are employed in the activity. Although coal mining in this area has recently slowed down because of the shift to crude oil as energy source, the spoils and waste still exist and might have enhanced the leaching of metals into the soil. Therefore, there is need to track the level of concentrations of metals in soil at the abandoned mine 
site. This will help to create awareness on the potential danger associated with the on-going action to revitalize coal mining in Nigeria as well as the risk of farming on lands close to the abandoned mine since there is presently, the challenges of land hunger in south east Nigeria. Although several studies have been carried out on mine sites, but most of the research were conducted at surface and mountaintop quarry sites. Furthermore, the research were not carried along crest, middle slope and valley. This study, therefore, is aimed to investigate soil chemical characteristics in different soil depths at crest, middle slope and valley in wet and dry season at a long wall underground mined site.

\section{MATERIALS AND METHODS}

Study area: The study on soil chemical characteristics in wet and dry season was carried out at Akwuke long wall underground mined site in Enugu State, Nigeria. Enugu with large deposits of sub-bituminous coal lies within latitude $\mathrm{N} 6^{\circ} 26^{\prime}$ and longitude $\mathrm{E} 7^{\circ} 27^{\prime}$ with an altitude of $251 \mathrm{~m}$. The climate of Enugu is made up of wet and dry seasons. The wet season is characterized by clouds driven by light winds, relatively constant temperatures, frequent rains and high humidity while the dry season is notably dry with little or no rainfall, hotter days, cooler nights, and lower humidity.

Sample collections and analysis of soil chemical characteristics: Soil samples were collected in February and June for dry and wet season at Akwuke mine and control site, respectively. Soil samples were randomly collected from ten different sampling points at the depth of $0-10,10-20$, and 20-30 cm with Dutch soil auger in four cardinal points (i.e. two sampling points each at north $(\mathrm{N})$, south $(\mathrm{S})$, east $(\mathrm{E})$, west $(\mathrm{W})$, and at the center $(\mathrm{C})$ of crest, middle slope and valley of mined site. The control sample was collected in a 5 year upland bush fallow about $2 \mathrm{~km}$ from the mined site where there was no visible source of contamination. Samples from each particular soil depth (e.g., 0-10 cm at N, S, E, W, and C) were placed in cellophane bags (about $25 \mathrm{~g}$ ), labeled well, placed in a wooden box and covered to avoid contamination from external sources and transferred to the laboratory for pre-treatment and analysis. Samples from the same soil depth were bulked together to give a composite sample which were homogenized and air-dried in a circulating air in the oven at $30^{\circ} \mathrm{C}$ to a constant weight and passed through a $2 \mathrm{~mm}$ sieve. Sub-samples from the composite samples were digested according to the method of Sharidah (1999).

The concentrations of $\mathrm{Ni}, \mathrm{Pb}, \mathrm{Cd}, \mathrm{As}$, and $\mathrm{Fe}$ in the digested samples were determined using flame Atomic Absorption Spectrophotometer (UNICAM 919 model) after calibrating the equipment with different standard concentrations as follows: $\mathrm{Cd}: 0.5,1$, and 2 ppm, $\mathrm{Pb}: 1$, 5, 10 ppm , Ni: 2, 5, 10 ppm, Fe: 1, 2, 5 ppm, and As:1, 4, $8 \mathrm{ppm}$. Triplicate digestion of each sample was carried out together with blank digest without the plant sample. $\mathrm{Ca}$ and $\mathrm{Mg}$ in the digest were determined by EDTA titration method, $\mathrm{K}$ and $\mathrm{P}$ was determined by flame photometry while total $\mathrm{N}$ was extracted by sulfur digestion and determined by the micro-Kjeldahl method (Nelson and Sommers, 1972). Organic matter levels in the air dried soils were estimated indirectly from organic $\mathrm{C}$. Organic $\mathrm{C}$ was determined by oxidation of organic matter with a hot mixture of $\mathrm{K}_{2} \mathrm{Cr}_{2} \mathrm{O}_{7}$ and $\mathrm{H}_{2} \mathrm{SO}_{4}$ using the Walkley and Black procedure (Walkley and Black, 1934). The amount of organic carbon was then determined by titration with $0.05 \mathrm{~N} \mathrm{FeSO} 4$ following the procedure outlined by Nelson and Sommers (1982). The organic matter content was obtained by multiplying the organic $\mathrm{C}$ content with the factor 1.729 (Nelson and Sommers, 1982) while soil $\mathrm{pH}$ was measured using $\mathrm{pH}$ meter DEMO 13702.93 manufactured by PHYWE of Germany.

Experimental design and data analysis: A single factor experiment was conducted in a randomized complete block design (RCBD) with 3 replications. Data collected on soil chemical characteristics were subjected to a 2-way analysis of variance (ANOVA) using special package for social sciences (SPSS) v. 15 and means were separated at $P<0.05$ using Duncan New Multiple Range Test (DNMRT).

\section{RESULTS AND DISCUSSION}

Soil pH, organic matter and macronutrient content in soil: The results on soil $\mathrm{pH}$, macronutrient $(\mathrm{Ca}, \mathrm{Mg}, \mathrm{K}$, $\mathrm{N}$, and $\mathrm{P}$ ), and soil organic matter content in soil at Akwuke mined site in wet and dry seasons is summarized in Table 1. The highest and the lowest values of soil $\mathrm{pH}$ were obtained at control site and mine site, respectively. Since there was no mining activity at the control site, the higher soil $\mathrm{pH}$ values at the control site may be attributed to the buffering effects of soil organic matter against $\mathrm{pH}$ change, in addition to the release of higher basic cations during organic matter decomposition (Oyedele et al., 2008). The $\mathrm{pH}(5.90 \pm-6.55 \pm 0.14)$ of the control site is higher than 4.14-6.14 obtained from Akwuke mined site. The high acidic nature of the mined site is attributed to flushes of acid mine drainage at Akwuke mine site. Soil $\mathrm{pH}$ ranged from 4.29-6.14 in wet season and 4.145.58 in dry season at Akwuke mine site. Soil acidity is higher in dry season than in wet season, which is as a result of dilution effect of rainfall. Within Akwuke mine site, soil $\mathrm{pH}$ was strongly acidic at the middle slope (4.14) than crest (4.22) and valley (5.39). Most 
metals do not exist in free form in the $\mathrm{pH}$ range of 6.0 to 9.0 (Adie and Etim, 2012). The $\mathrm{pH}$ for all middle slope samples analyzed in this study fell below this range (Table 1). It therefore, implies there would be high leaching of metals from the topsoil of the middle slope towards sub soils. Lower $\mathrm{pH}$ increase the solubility of metals (Gabriella and Anton, 2005) and this may have contributed to the higher concentration of heavy metals in middle slope of the mined site (Table 2).

Table 1: Macronutrient ( $\mathrm{cmol} / \mathrm{kg})$, soil $\mathrm{pH}$ and organic matter $(\%)$ content in soil at Akwuke mine site in wet and dry season

\begin{tabular}{|c|c|c|c|c|c|c|c|c|c|}
\hline Location & Depth & Season & Ca & Mg & K & $\mathbf{N}$ & $\mathbf{P}$ & $\mathrm{pH}\left(\mathrm{H}_{2} \mathrm{O}\right)$ & OM (\%) \\
\hline \multirow{12}{*}{ Crest } & \multirow{4}{*}{$0-10 \mathrm{~cm}$} & \multirow{3}{*}{ Wet } & $4.22^{\mathrm{efg}} \pm$ & $147.00^{1}$ & $179.10^{\mathrm{h}} \pm$ & $0.10^{\mathrm{e}} \pm$ & $0.20^{1} \pm$ & $4.60^{\mathrm{fgh}} \pm$ & $0.86^{\mathrm{c}} \pm$ \\
\hline & & & 0.06 & \pm 1.41 & 0.71 & 0.01 & 0.03 & 0.02 & 0.05 \\
\hline & & & $6.02^{\text {cde }} \pm$ & $251.90^{\mathrm{e}}$ & $119.55^{\mathrm{n}} \pm$ & $0.22^{\mathrm{de}} \pm$ & $0.34^{\text {ghi }} \pm$ & $4.34^{\mathrm{ij}} \pm$ & $0.96^{\mathrm{c}} \pm$ \\
\hline & & \multirow[t]{2}{*}{ Dry } & 0.14 & \pm 1.41 & 0.64 & 0.04 & 0.13 & 0.04 & 0.04 \\
\hline & \multirow{4}{*}{$10-20 \mathrm{~cm}$} & & $4.29^{\mathrm{efg}} \pm$ & $137.00^{\mathrm{jk}}$ & $183.90^{\mathrm{h}} \pm$ & $0.13^{\mathrm{e}} \pm$ & $0.34^{\text {ghi }} \pm$ & $4.53^{\mathrm{h}} \pm$ & $0.20^{\mathrm{b}} \pm$ \\
\hline & & Wet & 0.20 & \pm 2.12 & 1.56 & 0.03 & 0.03 & 0.03 & 0.01 \\
\hline & & & $8.12^{\mathrm{bc}} \pm$ & $183.20^{\mathrm{g}}$ & $87.10^{\circ} \pm$ & $0.29^{\mathrm{de}} \pm$ & $0.43^{\text {gh }} \pm$ & $4.39^{\mathrm{i}} \pm$ & $0.22^{\mathrm{e}} \pm$ \\
\hline & & Dry & 0.14 & \pm 0.42 & 0.57 & 0.06 & 0.06 & 0.06 & 0.00 \\
\hline & \multirow{4}{*}{$20-30 \mathrm{~cm}$} & & $4.25^{\mathrm{efg}} \pm$ & $142.00^{\mathrm{ij}}$ & $180.60^{\mathrm{h}} \pm$ & $0.16^{\mathrm{e}} \pm$ & $0.27^{\mathrm{hi}} \pm$ & $4.58^{\mathrm{gh}} \pm$ & $0.03^{\mathrm{g}} \pm$ \\
\hline & & Wet & 0.13 & \pm 1.41 & 1.56 & 0.03 & 0.03 & 0.05 & 0.01 \\
\hline & & & $4.11^{\mathrm{efg}} \pm$ & $168.00^{\mathrm{h}}$ & $158.00^{\mathrm{ij}} \pm$ & $0.20^{\mathrm{de}} \pm$ & $0.31^{\mathrm{hi}} \pm$ & $4.22^{\mathrm{jk}} \pm$ & $0.13^{\mathrm{f}} \pm$ \\
\hline & & Dry & 0.14 & \pm 0.28 & 12.73 & 0.03 & 0.04 & 0.08 & 0.04 \\
\hline \multirow{13}{*}{$\begin{array}{l}\text { Middle } \\
\text { slope }\end{array}$} & \multirow{5}{*}{$0-10 \mathrm{~cm}$} & \multirow{3}{*}{ Wet } & $2.81^{\mathrm{fgh}} \pm$ & $133.70 \mathrm{k}$ & $182.50^{\mathrm{h}} \pm$ & $0.12^{\mathrm{e}} \pm$ & $0.35^{\text {ghi }} \pm$ & $4.68^{\mathrm{fg}} \pm$ & $0.64^{\mathrm{d}} \pm$ \\
\hline & & & 0.11 & \pm 1.27 & 0.85 & 0.01 & 0.03 & 0.02 & 0.05 \\
\hline & & & $4.16^{\mathrm{efg}} \pm$ & $169.00^{\mathrm{h}}$ & $95.60^{\circ} \pm$ & $0.28^{\mathrm{de}} \pm$ & $0.38^{\text {ghi }} \pm$ & $4.31^{\mathrm{ijk}} \pm$ & $0.75^{\text {cd }}$ \\
\hline & & \multirow[t]{2}{*}{ Dry } & 0.06 & \pm 1.13 & 0.99 & 0.06 & 0.04 & 0.08 & \pm 0.01 \\
\hline & & & $1.65^{\mathrm{gh}} \pm$ & $115.10^{\mathrm{m}}$ & $156.10^{\mathrm{jk}} \pm$ & $0.14^{\mathrm{e}} \pm$ & $0.42^{\mathrm{gh}} \pm$ & $4.72^{\mathrm{f}} \pm$ & $0.11^{\mathrm{f}} \pm$ \\
\hline & \multirow[t]{3}{*}{$10-20 \mathrm{~cm}$} & \multirow[t]{2}{*}{ Wet } & 0.03 & \pm 0.71 & 0.42 & 0.03 & 0.01 & 0.02 & 0.01 \\
\hline & & & $4.09^{\mathrm{efg}} \pm$ & $121.80^{1}$ & $151.80^{\mathrm{jk}} \pm$ & $0.36^{\mathrm{de}} \pm$ & $0.46^{\text {gh }} \pm$ & $4.19^{\mathrm{kl}} \pm$ & $0.12^{\mathrm{f}} \pm$ \\
\hline & & \multirow[t]{2}{*}{ Dry } & 0.04 & \pm 1.27 & 0.57 & 0.03 & 0.04 & 0.05 & 0.00 \\
\hline & \multirow{4}{*}{$20-30 \mathrm{~cm}$} & & $2.20^{\mathrm{gh}} \pm$ & $123.00^{1}$ & $168.00^{\mathrm{i}} \pm$ & $0.17^{\mathrm{de}} \pm$ & $0.39^{\text {ghi }} \pm$ & $4.29^{\mathrm{jk}} \pm$ & $0.02^{\mathrm{g}} \pm$ \\
\hline & & \multirow[t]{2}{*}{ Wet } & 0.06 & \pm 0.85 & 14.14 & 0.03 & 0.04 & 0.03 & 0.01 \\
\hline & & & $2.00^{\mathrm{gh}} \pm$ & $108.00^{\mathrm{n}}$ & $122.10^{\mathrm{n}} \pm$ & $0.24^{\mathrm{de}} \pm$ & $0.52^{\mathrm{g}} \pm$ & $4.14^{1} \pm$ & $0.06^{\mathrm{g}} \pm$ \\
\hline & & \multirow[t]{2}{*}{ Dry } & 0.20 & \pm 0.85 & 0.71 & 0.06 & 0.06 & 0.03 & 0.03 \\
\hline & \multirow{5}{*}{$0-10 \mathrm{~cm}$} & & $1.21^{\mathrm{h}} \pm$ & $86.25^{\circ} \pm$ & $145.95^{\mathrm{kl}} \pm$ & $0.11^{\mathrm{e}} \pm$ & $0.28^{\text {hi }} \pm$ & $6.10^{\mathrm{b}} \pm$ & $0.15^{\mathrm{f}} \pm$ \\
\hline \multirow[t]{12}{*}{ Valley } & & \multirow[t]{2}{*}{ Wet } & 0.04 & 0.21 & 0.64 & 0.01 & 0.06 & 0.13 & 0.04 \\
\hline & & & $4.02^{\mathrm{efg}} \pm$ & $193.50^{\mathrm{f}}$ & $126.80^{\mathrm{mn}}$ & $0.19^{\mathrm{de}} \pm$ & $0.33^{\text {ghi }} \pm$ & & $0.28^{\mathrm{e}} \pm$ \\
\hline & & \multirow[t]{2}{*}{ Dry } & 0.13 & \pm 0.85 & \pm 1.27 & 0.04 & 0.06 & $5.39^{\mathrm{e}} \pm 0.07$ & 0.02 \\
\hline & & & $2.05^{\text {gh }} \pm$ & $68.30^{\mathrm{q}} \pm$ & $124.70^{\mathrm{n}} \pm$ & $0.14^{\mathrm{e}} \pm$ & $0.36^{\text {ghi }} \pm$ & $6.14^{\mathrm{b}} \pm$ & $0.05^{\mathrm{g}} \pm$ \\
\hline & $10-20 \mathrm{~cm}$ & Wet & 0.07 & 0.71 & 1.70 & 0.03 & 0.03 & 0.04 & 0.01 \\
\hline & & & $1.05^{\mathrm{h}} \pm$ & $120.20^{\mathrm{Im}}$ & $212.00^{\mathrm{f}} \pm$ & $0.23^{\mathrm{de}} \pm$ & $0.41^{\mathrm{gh}} \pm$ & & $0.03^{\mathrm{g}} \pm$ \\
\hline & & Dry & 0.07 & \pm 0.85 & 0.57 & 0.14 & 0.04 & $5.39^{\mathrm{e}} \pm 0.21$ & 0.01 \\
\hline & & & $1.70^{\mathrm{gh}} \pm$ & $78.00^{\mathrm{p}} \pm$ & $136.40^{\mathrm{Im}} \pm$ & $0.13^{\mathrm{e}} \pm$ & $0.30^{\mathrm{hi}} \pm$ & & $0.01^{\mathrm{gh}} \pm$ \\
\hline & $20-30 \mathrm{~cm}$ & Wet & 0.08 & 0.57 & 0.28 & 0.01 & 0.06 & $5.83^{\mathrm{c}} \pm 0.05$ & 0.00 \\
\hline & & & $1.16^{\mathrm{h}} \pm$ & $89.60^{\circ} \pm$ & $158.20^{\mathrm{ij}} \pm$ & $0.19^{\mathrm{de}} \pm$ & $0.42^{\mathrm{gh}} \pm$ & $5.58^{\mathrm{d}} \pm$ & $0.01^{\mathrm{gh}} \pm$ \\
\hline & & Dry & 0.16 & 1.41 & 0.57 & 0.14 & 0.04 & 0.02 & 0.00 \\
\hline & & & $9.60^{\mathrm{b}} \pm$ & $301.10^{\mathrm{d}}$ & $422.00^{\mathrm{b}} \pm$ & $0.81^{\mathrm{c}} \pm$ & $2.94^{\mathrm{f}} \pm$ & & $20.66^{\mathrm{a}} \pm$ \\
\hline Control & $0-10 \mathrm{~cm}$ & Wet & 0.08 & \pm 0.85 & 0.57 & 0.08 & 0.11 & $6.52^{a} \pm 0.06$ & 0.08 \\
\hline & & & $12.04^{\mathrm{a}} \pm$ & $380.00^{\mathrm{a}}$ & $471.00^{\mathrm{a}} \pm$ & $1.46^{\mathrm{a}} \pm$ & $3.21^{\mathrm{e}} \pm$ & & $26.21^{\mathrm{a}} \pm$ \\
\hline & & Dry & 0.08 & \pm 1.13 & 4.24 & 0.10 & 0.27 & $6.55^{\mathrm{a}} \pm 0.14$ & 0.34 \\
\hline & & & $7.14^{\text {bcd }} \pm$ & $310.00^{c}$ & $280.10^{\mathrm{d}} \pm$ & $0.92^{\mathrm{c}} \pm$ & $4.01^{\mathrm{d}} \pm$ & & $1.06^{\mathrm{c}} \pm$ \\
\hline & $10-20 \mathrm{~cm}$ & Wet & 0.23 & \pm 12.73 & 0.85 & 0.08 & 0.16 & $6.48^{a} \pm 0.08$ & 0.07 \\
\hline & & & $9.20^{\mathrm{b}} \pm$ & $367.10^{\mathrm{b}}$ & $316.00^{c} \pm$ & $1.20^{\mathrm{b}} \pm$ & $4.40^{\mathrm{c}} \pm$ & $6.19^{\mathrm{b}} \pm$ & $1.15^{\mathrm{b}} \pm$ \\
\hline & & Dry & 0.07 & \pm 4.10 & 13.86 & 0.16 & 0.03 & 0.03 & 0.09 \\
\hline & & & $4.03^{\mathrm{efg}} \pm$ & $198.10^{\mathrm{f}}$ & $200.00^{\mathrm{g}} \pm$ & $0.44^{\mathrm{d}} \pm$ & $5.82^{\mathrm{b}} \pm$ & $6.24^{\mathrm{b}} \pm$ & $0.00^{\text {gh }} \pm$ \\
\hline & $20-30 \mathrm{~cm}$ & Wet & 0.13 & \pm 0.85 & 2.83 & 0.45 & 0.01 & 0.04 & 0.00 \\
\hline & & & $5.16^{\mathrm{def}} \pm$ & $248.00^{\mathrm{e}}$ & $224.00^{\mathrm{e}} \pm$ & $1.01^{\mathrm{bc}} \pm$ & $6.28^{\mathrm{a}} \pm$ & & $0.00^{\mathrm{gh}} \pm$ \\
\hline & & Dry & 0.14 & \pm 1.56 & 1.70 & 0.01 & 0.14 & $5.90^{\mathrm{c}} \pm 0.10$ & 0.00 \\
\hline
\end{tabular}

$a, b, c, d, e, f, g, h, i, j, k, l, m, n, o, p, q$ means in a column with different superscript are significantly different $(P<0.05)$

Values are mean \pm standard deviation of 3 replications; $\mathrm{OM}=$ organic matter

The highest and the lowest organic matter content in soil is recorded at control site and mine site. The high organic matter content in soil at the control site is associated with the release of more organic matter materials (litterfall) by plants growing on the control plot and possible droppings as well as remains of animals that inhabited the area. Low organic matter are characteristics feature of mine degraded soils
(Pokethitiyook, 2008) which tend to inhibit soil forming processes (Weis and Weis, 2004). The highest content of organic matter in soil at Akwuke mined site is recorded in dry season at $0-10 \mathrm{~cm}$ valley $(0.96 \pm 0.04 \%)$. The organic matter content in soil in wet and dry season was higher at $0-10 \mathrm{~cm}$ than $10-20$ and $20-30 \mathrm{~cm}$ at the mined site. The result is in conformity with the findings that organic matter 
content decreases with soil depth (Orimoloye, 2011). The magnitude of decline in organic matter content with depth varied amongst sampling locations (crest, middle slope, and valley) but the rate of decline were highest in valley, followed by middle slope, and lastly crest. The macronutrient content in soils at Akwuke mine and the control site in wet and dry seasons indicate that the highest and the lowest macro-nutrient content in soils were observed at the control site and mine site, respectively (Table 1). The higher content of macronutrient observed at the control site may be attributed to the quality and quantity of litterfall released by the different plant species standing on the control site unlike the Akwuke mine site.

\begin{tabular}{|c|c|c|c|c|c|c|c|}
\hline Location & Depth (cm) & Season & $\mathrm{Ni}$ & $\mathbf{P b}$ & As & $\mathrm{Fe}$ & Cd \\
\hline \multirow[t]{6}{*}{ Crest } & $0-10$ & Rainy & $9.71^{\mathrm{efg}} \pm 0.16$ & $15.45^{\mathrm{bc}} \pm 0.18$ & $0.00 \pm 0.00$ & $417.00^{f} \pm 1.98$ & $1.73^{\mathrm{c}} \pm 0.06$ \\
\hline & & Dry & $4.15^{\mathrm{k}} \pm 0.07$ & $12.65^{\mathrm{cd}} \pm 0.13$ & $0.00 \pm 0.00$ & $296.10^{\mathrm{k}} \pm 8.63$ & $0.68^{\mathrm{de}} \pm 0.07$ \\
\hline & $10-20$ & Rainy & $11.72^{\mathrm{d}} \pm 0.07$ & $15.80^{\mathrm{bc}} \pm 0.28$ & $0.00 \pm 0.00$ & $480.70^{c} \pm 2.40$ & $0.72^{\mathrm{d}} \pm 0.17$ \\
\hline & & Dry & $10.04^{\mathrm{ef}} \pm 0.20$ & $10.45^{\mathrm{de}} \pm 0.07$ & $0.00 \pm 0.00$ & $290.00^{\mathrm{k}} \pm 4.95$ & $0.07^{\mathrm{gh}} \pm 0.03$ \\
\hline & $20-30$ & Rainy & $14.30^{c} \pm 0.71$ & $17.62^{b} \pm 0.08$ & $0.00 \pm 0.00$ & $522.00^{\mathrm{a}} \pm 1.98$ & $0.61^{\mathrm{de}} \pm 0.13$ \\
\hline & & Dry & $8.24^{\mathrm{hi}} \pm 0.20$ & $13.60^{\mathrm{cd}} \pm 0.28$ & $0.00 \pm 0.00$ & $216.40^{\mathrm{n}} \pm 1.27$ & $0.38^{\mathrm{f}} \pm 0.03$ \\
\hline \multirow[t]{6}{*}{ Middle slope } & $0-10$ & Rainy & $10.45^{\mathrm{e}} \pm 0.27$ & $15.10^{\mathrm{bc}} \pm 0.28$ & $0.00 \pm 0.00$ & $428.10^{\mathrm{e}} \pm 0.85$ & $2.92^{\mathrm{b}} \pm 0.03$ \\
\hline & & Dry & $6.04^{j} \pm 0.06$ & $10.41^{\mathrm{de}} \pm 0.11$ & $0.00 \pm 0.00$ & $362.20^{\mathrm{i}} \pm 4.53$ & $0.10^{\mathrm{gh}} \pm 0.04$ \\
\hline & $10-20$ & Rainy & $11.65^{\mathrm{d}} \pm 0.11$ & $12.60^{\mathrm{cd}} \pm 0.35$ & $0.00 \pm 0.00$ & $458.00^{d} \pm 2.12$ & $0.17^{\mathrm{g}} \pm 0.06$ \\
\hline & & Dry & $8.04^{\mathrm{i}} \pm 0.20$ & $8.21^{\mathrm{ef}} \pm 0.44$ & $0.00 \pm 0.00$ & $267.60^{1} \pm 1.56$ & $0.01^{\mathrm{h}} \pm 0.01$ \\
\hline & $20-30$ & Rainy & $12.02^{\mathrm{d}} \pm 0.48$ & $10.30^{\mathrm{de}} \pm 0.57$ & $0.00 \pm 0.00$ & $506.70^{\mathrm{b}} \pm 0.42$ & $0.08^{\mathrm{gh}} \pm 0.01$ \\
\hline & & Dry & $9.20^{\mathrm{fgh}} \pm 0.42$ & $6.11^{\mathrm{f}} \pm 0.13$ & $0.00 \pm 0.00$ & $314.00^{\mathrm{j}} \pm 1.56$ & $0.02^{\mathrm{h}} \pm 0.01$ \\
\hline \multirow[t]{6}{*}{ Valley } & $0-10$ & Rainy & $8.85^{\text {ghi }} \pm 0.35$ & $15.26^{\mathrm{bc}} \pm 6.87$ & $0.00 \pm 0.00$ & $397.80^{\mathrm{g}} \pm 11.03$ & $3.06^{\mathrm{a}} \pm 0.08$ \\
\hline & & Dry & $6.07^{\mathrm{j}} \pm 0.10$ & $17.50^{\mathrm{b}} \pm 0.42$ & $0.00 \pm 0.00$ & $389.80^{\mathrm{h}} \pm 0.28$ & $0.08^{\mathrm{gh}} \pm 0.03$ \\
\hline & $10-20$ & Rainy & $16.03^{\mathrm{b}} \pm 0.21$ & $21.10^{\mathrm{a}} \pm 0.85$ & $0.00 \pm 0.00$ & $258.70^{\mathrm{m}} \pm 0.42$ & $0.57^{\mathrm{e}} \pm 0.10$ \\
\hline & & Dry & $10.04^{\mathrm{ef}} \pm 1.47$ & $15.65^{\mathrm{bc}} \pm 0.35$ & $0.00 \pm 0.00$ & $207.80^{\circ} \pm 3.11$ & $0.05^{\mathrm{gh}} \pm 0.03$ \\
\hline & $20-30$ & Rainy & $19.81^{\mathrm{a}} \pm 1.29$ & $21.72^{\mathrm{a}} \pm 0.69$ & $0.00 \pm 0.00$ & $203.00^{\circ} \pm 4.24$ & $0.29^{f} \pm 0.01$ \\
\hline & & Dry & $12.01^{\mathrm{d}} \pm 0.16$ & $13.28^{\mathrm{cd}} \pm 0.11$ & $0.00 \pm 0.00$ & $186.00^{\mathrm{p}} \pm 2.83$ & $0.11^{\mathrm{gh}} \pm 0.03$ \\
\hline \multirow[t]{6}{*}{ Control } & $0-10$ & Rainy & $0.02^{1} \pm 0.00$ & $1.46^{\mathrm{g}} \pm 0.23$ & $0.00 \pm 0.00$ & $70.60^{\mathrm{s}} \pm 1.98$ & $0.01^{\mathrm{h}} \pm 0.00$ \\
\hline & & Dry & $0.02^{1} \pm 0.00$ & $0.72^{\mathrm{g}} \pm 0.04$ & $0.00 \pm 0.00$ & $43.00^{\mathrm{u}} \pm 0.99$ & $0.00^{\mathrm{h}} \pm 0.00$ \\
\hline & $10-20$ & Rainy & $0.01^{1} \pm 0.00$ & $1.01^{g} \pm 0.16$ & $0.00 \pm 0.00$ & $82.00^{r} \pm 2.83$ & $0.00^{\mathrm{h}} \pm 0.00$ \\
\hline & & Dry & $0.00^{1} \pm 0.00$ & $0.40^{g} \pm 0.04$ & $0.00 \pm 0.00$ & $38.50^{\mathrm{u}} \pm 0.99$ & $0.00^{\mathrm{h}} \pm 0.00$ \\
\hline & $20-30$ & Rainy & $0.01^{1} \pm 0.01$ & $0.26^{g} \pm 0.04$ & $0.00 \pm 0.00$ & $101.00^{\mathrm{q}} \pm 4.24$ & $0.00^{\mathrm{h}} \pm 0.00$ \\
\hline & & Dry & $0.00^{1} \pm 0.00$ & $0.22^{\mathrm{g}} \pm 0.14$ & $0.00 \pm 0.00$ & $62.20^{t} \pm 1.41$ & $0.00^{\mathrm{h}} \pm 0.00$ \\
\hline
\end{tabular}

$a, b, c, \overline{d, e, f, g, h, i, j, k, l, m, n, o, p, q, r, s, t, u}$ means in a column with different superscript are significantly different $(P<0.05) ;$ Values are mean \pm standard deviation of 3 replications

The highest content of $\mathrm{Ca}(12.04 \pm 0.08 \mathrm{cmol} / \mathrm{kg}), \mathrm{Mg}$ $(380 \pm 1.13 \mathrm{cmol} / \mathrm{kg}), \quad \mathrm{K} \quad(471 \pm 4.24 \mathrm{cmol} / \mathrm{kg}), \quad \mathrm{N}$ $(1.46 \pm 0.10 \mathrm{cmol} / \mathrm{kg})$, and $\mathrm{P}(6.53 \pm 0.49 \mathrm{cmol} / \mathrm{kg})$ in soil were obtained in $0-10 \mathrm{~cm}$ at control site in dry season and these values are significantly $(\mathrm{P}<0.05)$ higher than the corresponding values of $\mathrm{Ca}(8.12 \pm 0.14$ $\mathrm{cmol} / \mathrm{kg}), \mathrm{Mg}(251.9 \pm 1.41 \mathrm{cmol} / \mathrm{kg}), \mathrm{K}(212 \pm 0.57$ $\mathrm{cmol} / \mathrm{kg}), \mathrm{N}(0.36 \pm 0.03 \mathrm{col} / \mathrm{kg})$, and $\mathrm{P}(0.52 \pm 0.06$ $\mathrm{cmol} / \mathrm{kg}$ ) observed at Akwuke mined site. The low values of $\mathrm{Ca}, \mathrm{Mg}, \mathrm{K}, \mathrm{N}$, and $\mathrm{P}$ at Akwuke mined site is attributed to coal mining activities that involved removal of vegetation to access coal resources from the soil. The removal of vegetation at the Akwuke mine site disrupted the transfer of macronutrients in soil-plant system which altered the cycling of aboveground forest organic materials and their incorporation into the soil at the mine site. The values of these macronutrients $(\mathrm{Ca}, \mathrm{Mg}, \mathrm{K}, \mathrm{N}$, and $\mathrm{P})$ at the control site was $14.52,13.40,25.25,41.99$, and $70.96 \%$ higher than the highest values recorded at Akwuke mined site. The high organic matter content in soil at the control site (Table 1) is implicated for the higher percentage of macronutrients at the control site. These results corroborate the finding that macronutrient content in unpolluted soil is higher than the levels observed in metal contaminated soil (Ogbonna and Okezie, 2011). Among all the macronutrient investigated in soils at Akwuke mined site, $\mathrm{Mg}(251.9 \pm 1.41 \mathrm{cmol} / \mathrm{kg})$ recorded the highest content in soils, which was obtained at $0-10 \mathrm{~cm}$ crest in dry season (Table 1). The value of $\mathrm{Mg}(251.9 \pm 1.41$ $\mathrm{cmol} / \mathrm{kg}$ ) in soil at the mined site in dry season is 
significantly $(\mathrm{P}<0.05)$ higher than $147.0 \pm 1.41 \mathrm{cmol} / \mathrm{kg}$ observed in wet season. The higher content of organic matter in soil in dry season $(0.96 \pm 0.04 \%)$ is implicated for the higher content of $\mathrm{Mg}$ in dry season at the mined site (Table 1). The value of $\mathrm{Mg}(89.60 \pm 1.41$ to $251.9 \pm 1.41 \mathrm{cmol} / \mathrm{kg}$ ) in soil in dry season is higher than $68.30 \pm 0.71$ to $147.0 \pm 1.41 \mathrm{cmol} / \mathrm{kg}$ in wet season and this may be attributed to the high level of organic matter in soil in dry season at Akwuke mine site. The level of $\mathrm{Mg}$ in soil at Akwuke coal mine site is substantially below 7,000 to $197,000 \mathrm{mg} / \mathrm{kg}$ observed in soil at Magnesite mining area in Jelšava and Lubeník in Slovakia (Fazekašová et al., 2018) and $4,590 \pm 1,029 \mu \mathrm{g} \mathrm{g}{ }^{1}$ reported at a coal mine site in southern part of Santa Catarina State, Brazil (Zocche et al., 2017). The highest content of $\mathrm{N}(0.36 \pm 0.03$ $\mathrm{cmol} / \mathrm{kg})$ and $\mathrm{P}(0.52 \pm 0.06 \mathrm{cmol} / \mathrm{kg})$ in soil obtained in dry season at $10-20 \mathrm{~cm}$ and $20-30 \mathrm{~cm}$ middle slope of Akwuke mine is higher than $0.17 \pm 0.0$ and $0.42 \pm 0.01 \mathrm{cmol} / \mathrm{kg}$ recorded in wet season at $20-30 \mathrm{~cm}$ and $10-20 \mathrm{~cm}$ middle slope of the mine site. Since south eastern agro ecological zone of Nigeria is known for high rainfall, the high content of $\mathrm{N}$ and $\mathrm{P}$ at 10-20 and $20-30 \mathrm{~cm}$ at Akwuke mine site is associated with the leaching of these macronutrients $(\mathrm{N}$ and $\mathrm{P})$ into lower depths by rainfall. The value of $\mathrm{N}$ in soil range from $0.19 \pm 0.14$ to $0.36 \pm 0.03 \mathrm{cmol} / \mathrm{kg}$ in dry season, which is higher than $0.10 \pm 0.01$ to $0.17 \pm 0.03 \mathrm{cmol} / \mathrm{kg}$ in wet season, and the value of $\mathrm{P}$ in soil range from $0.31 \pm 0.04$ to $0.52 \pm 0.06 \mathrm{cmol} / \mathrm{kg}$ in dry season, which is higher than $0.20 \pm 0.03$ to $0.42 \pm 0.01 \mathrm{cmol} / \mathrm{kg}$ in wet season. The low content of $\mathrm{N}$ and $\mathrm{P}$ in wet season may be attributed to leaching and diluting effect of rainfall during the wet season. Similarly, metal toxicity may lead to inhibition of enzymes such as phosphates (an enzyme splitting off phosphates from organic molecules) present in soil, hence, affecting the availability of $\mathrm{P}$ in the mined site (Ogbonna et al., 2011). The value of $\mathrm{N}(0.10 \pm 0.01$ to $0.36 \pm 0.03$ $\mathrm{cmol} / \mathrm{kg}$ ) in soil is relatively higher than $0.11 \pm 0.00$ to $0.34 \pm 0.00 \mathrm{cmol} / \mathrm{kg}$ obtained in a roadside soil in Umuahia, Nigeria (Ogbonna and Okeke, 2011).

Calcium in soil range from $1.05 \pm 0.07$ to $8.12 \pm 0.14$ $\mathrm{cmol} / \mathrm{kg}$ in dry season, which is higher than $1.21 \pm 0.04$ to $4.29 \pm 0.20 \mathrm{cmol} / \mathrm{kg}$ in wet season. The high level of organic matter in soil during the dry season at Akwuke mine site is implicated for the high content of $\mathrm{Ca}$ in soil in dry season The values of $\mathrm{Ca}(1.05 \pm 0.07$ to $8.12 \pm 0.14 \mathrm{cmol} / \mathrm{kg}$ ) in soil at Akwuke coal mine site is higher than 1.86 to $2.10 \mathrm{mg} / \mathrm{kg}$ reported by Derome and Nieminen (1998) in their study on metal and macronutrient fluxes in heavy metal polluted scots pine ecosystems in SW Finland. The highest value of $\mathrm{K}(212.00 \pm 0.57)$ in soil was observed in dry season at $10-20 \mathrm{~cm}$ valley of Akwuke mine site. The high content of organic matter in dry season is implicated for the high content of $\mathrm{K}$ at Akwuke mine. It is observed that the level of $\mathrm{K}$ in soil $(87.10 \pm 0.57$ to $212.00 \pm 0.57 \mathrm{mg} / \mathrm{kg}$ ) in dry season is higher than the level $(126.80 \pm 1.27$ to $183.90 \pm 1.56 \mathrm{mg} / \mathrm{kg})$ in wet season. The high content of organic matter in soil during the dry season is implicated for the high $\mathrm{K}$ in soil in dry season at Akwuke mine site. The values of $\mathrm{K}$ in this study $(87.10 \pm 0.57$ to $212.00 \pm 0.57 \mathrm{mg} / \mathrm{kg})$ is relatively higher than $8.70 \pm 0.40$ to $14.06 \pm 0.00 \mathrm{mg} / \mathrm{kg}$ reported for $\mathrm{K}$ in soil at Udege tin/columbite mine site in Nasarawa State, Nigeria (Aremu et al., 2010). The values of $\mathrm{N}, \mathrm{P}, \mathrm{K}, \mathrm{Ca}$, and $\mathrm{Mg}$ in soil at Akwuke mine were higher in dry season than in wet season and this may be attributed to the fact that macro elements are easily leached, transported or washed away by runoff in wet season, thus, reducing the quantity of these elements available for plant uptake in wet season. Indeed, the pattern of result is in the increasing order: $\mathrm{N}<\mathrm{P}<\mathrm{Ca}<\mathrm{K}<\mathrm{Mg}$.

Heavy metal concentration in soil: The concentration of heavy metal in soils of mined and unmined (control) sites is summarized in Table 2. The comparison in this study is on the concentrations of the control soils (background soils) and concentrations in mined sites obtained in a number of research works in other cities globally. The results indicate that the highest and the lowest metal concentrations in soil were observed at the mined site and control site, respectively. Since there were no other sources of contamination in the area, the high concentrations of metals in soils of the mined site (unlike the control site) may be attributed to mine spoil from the abandoned mine. Spoil heaps and tailings from excavations constitute the overburdens deposited as mine wastes on surface soil (Mahboob, 2001) and these wastes contain heavy metals that are leached, transported and deposited on soil. Soil concentrations of all metals except arsenic (As) were raised to different degrees in wet and dry season at Akwuke mined site. The concentrations of heavy metal at Akwuke mined site were significantly raised compared to those at the control site, and significant differences was evidenced amongst the three sampling position (crest, middle slope, and valley). The tailings dumped indiscriminately at mines can influence the natural concentrations of heavy metals in soil (Giachetti and Sebastiani, 2006).

The highest concentration of Fe $(522.00 \pm 1.98 \mathrm{mg} / \mathrm{kg})$ in soil at Akwuke mine is observed at $20-30 \mathrm{~cm}$ crest in wet season and it is significantly $(\mathrm{P}<0.05)$ higher than values obtained at middle slope $(428.10 \pm 0.85$ and $362.20 \pm 4.53 ; \quad 458.00 \pm 2.12$ and $267.60 \pm 1.56$; $506.70 \pm 0.42 \mathrm{mg} / \mathrm{kg})$, valley $(397.80 \pm 11.03$ and $389.80 \pm 0.28 ; \quad 258.70 \pm 0.42$ and $207.80 \pm 3.11$; 
203.00 \pm 4.24 and $186.00 \pm 2.83)$, and the control site $(70.60 \pm 1.98$ and $43.00 \pm 0.99 ; 82.00 \pm 2.83$ and $38.50 \pm 0.99 ; 101.00 \pm 4.24$ and $62.20 \pm 1.41 \mathrm{mg} / \mathrm{kg}$ ) at 0 $10,10-20$, and $20-30 \mathrm{~cm}$ (Table 2). The high content of $\mathrm{Fe}$ at the $20-30 \mathrm{~cm}$ depth may be attributed to low content of organic matter in surface soil that enhanced the leaching of this metallic element to $20-30 \mathrm{~cm}$ over time. The result is similar to the findings of Fagbote and Olanipekun (2010) that reported higher concentration of $\mathrm{Fe}$ in sediment during the wet season than dry season at Agabu bitumen deposit, Ondo State, Nigeria. The values of $\mathrm{Fe}$ in soil range from $(186.00 \pm 2.83$ to $522.00 \pm 1.98 \mathrm{mg} / \mathrm{kg})$ at Akwuke mine, which is higher than 102.17 to $181.08 \mathrm{mg} / \mathrm{kg}$ (Mahboob, 2001) at a mined site in Osun State, Nigeria (Table 3). The highest concentrations of $\mathrm{Pb}$ $(21.72 \pm 0.69 \mathrm{mg} / \mathrm{kg})$ in soil was obtained in wet season at $20-30 \mathrm{~cm}$ valley of Akwuke mine and it is significantly $(\mathrm{P}<0.05)$ higher than values at crest
$(15.45 \pm 0.18$ and $12.65 \pm 0.13 ; 15.80 \pm 0.28$ and 10.45 $\pm 0.07 ; 17.62 \pm 0.08$ and $13.60 \pm 0.28 \mathrm{mg} / \mathrm{kg})$, middle slope $(15.10 \pm 0.28$ and $10.41 \pm 0.11 ; 12.60 \pm 0.35$ and $8.21 \pm 0.44 ; 10.30 \pm 0.57$ and $6.11 \pm 0.13 \mathrm{mg} / \mathrm{kg})$ and control site $(1.46 \pm 0.23$ and $0.72 \pm 0.04 ; 1.01 \pm 0.16$ and $0.40 \pm 0.04 ; 0.26 \pm 0.04$ and $0.22 \pm 0.14 \mathrm{mg} / \mathrm{kg}$ ) at $0-10,10-20$ and $20-30 \mathrm{~cm}$ (Table 2). The high concentrations of soil $\mathrm{Pb}$ in wet season may be attributed to mine wastes (overburden) that contain metals that are leached, transported and deposited in soils in wet season. The concentration of $\mathrm{Pb}(6.11 \pm$ $0.13-21.10 \pm 0.85 \mathrm{mg} / \mathrm{kg}$ ) in soil at Akwuke mine is lower than 21-484 mg/kg in soils at the Daduk Au-Ag$\mathrm{Pb}-\mathrm{Zn}$ mine, Korea (Chon et al., 2001), 2.5-36.3 $\mathrm{mg} / \mathrm{kg}$ in soils at Zacatecas mine, Mexico (Gonzalez and Gonzalez-Chavez, 2006) and the background values of $11.50-38.20 \mathrm{mg} / \mathrm{kg}$ in Beijing, China (Chen et al., 2004).

\begin{tabular}{|c|c|c|c|c|}
\hline $\begin{array}{l}\text { Heavy } \\
\text { metals }\end{array}$ & $\begin{array}{l}\text { Levels obtained in } \\
\text { this study (mg/kg) }\end{array}$ & $\begin{array}{l}\text { Ranges of } \\
\text { values }(\mathbf{m g} / \mathbf{k g})\end{array}$ & $\begin{array}{l}\text { Locations in } \\
\text { Nigeria } \\
\end{array}$ & Authors \\
\hline $\mathrm{Cd}$ & $0.01-3.06$ & $\begin{array}{l}28.8-126.0 \\
0.42-0.70 \\
26-210 \\
0.8-6.0\end{array}$ & $\begin{array}{l}\text { Enyigba, Ebonyi } \\
\text { State } \\
\text { Odo Illesa, Osun } \\
\text { State } \\
\text { Arufu, Benue State } \\
\text { Benue State }\end{array}$ & $\begin{array}{l}\text { Oti and Nwabue (2013) } \\
\text { Ekwue } \text { et al., } 2012 \\
\text { Adamu } \text { et al. (2011); } \\
\text { Nganje and Adamu (2010) }\end{array}$ \\
\hline $\mathrm{Ni}$ & $4.15-79.00$ & $\begin{array}{l}2.0-39.5 \\
6.34-17.4\end{array}$ & $\begin{array}{l}\text { Ishiagu, Ebonyi } \\
\text { State } \\
\text { Osun State }\end{array}$ & $\begin{array}{l}\text { Eze and Chukwu (2011) } \\
\text { Adie and Etim (2012) }\end{array}$ \\
\hline $\mathrm{Fe}$ & $186.0-522.0$ & $\begin{array}{l}102.17-181.08 \\
2.12-4.8\end{array}$ & $\begin{array}{l}\text { Osun State } \\
\text { Enyigba, Ebonyi }\end{array}$ & $\begin{array}{l}\text { Mahboob (2001) } \\
\text { Oti and Nwabue (2013) }\end{array}$ \\
\hline As & $0.001-0.003$ & $\begin{array}{l}8.0-18.0 \\
1.72-2.00\end{array}$ & $\begin{array}{l}\text { State } \\
\text { Benue State } \\
\text { Odo Illesa, Osun } \\
\text { State }\end{array}$ & $\begin{array}{l}\text { Nganje and Adamu (2010) } \\
\text { Ekwue } \text { et al., } 2012\end{array}$ \\
\hline $\mathrm{Pb}$ & $6.11-81.60$ & $\begin{array}{l}91.7-1,116.8 \\
11.5-27.7 \\
8.00-15.00\end{array}$ & $\begin{array}{l}\text { Enyigba, Ebonyi } \\
\text { State } \\
\text { Osun State } \\
\text { Odo Illesa, Osun } \\
\text { State }\end{array}$ & $\begin{array}{l}\text { Oti and Nwabue (2013); } \\
\text { Adie and Etim (2012) } \\
\text { Ekwue } \text { et al., 2012 }\end{array}$ \\
\hline
\end{tabular}

The highest concentration of $\mathrm{Ni}(19.81 \pm 1.29 \mathrm{mg} / \mathrm{kg})$ in soil in wet season is observed at $20-30 \mathrm{~cm}$ valley of Akwuke mine and the values are significantly $(\mathrm{P}<0.05)$ higher than values at crest $(9.71 \pm 0.16$ and $4.15 \pm 0.07 ; 11.72 \pm 0.07$ and $10.04 \pm 0.20 ; 14.30 \pm$ 0.71 and $8.24 \pm 0.20 \mathrm{mg} / \mathrm{kg})$, middle slope $(10.45 \pm$ 0.27 and $6.04 \pm 0.06 ; 11.65 \pm 0.11$ and $8.04 \pm 0.20$; $12.02 \pm 0.48$ and $9.20 \pm 0.42 \mathrm{mg} / \mathrm{kg}$ ) and control site $(0.02 \pm 0.00 \mathrm{mg} / \mathrm{kg})$, at $0-10,10-20$ and $20-30 \mathrm{~cm}$ (Table 2). The high moisture level in wet season that carried large volume of acid mine drainage may be responsible for the increase concentration of $\mathrm{Ni}$ in soil in wet season. The concentration of $\mathrm{Ni}(4.15 \pm 0.07$ to $19.81 \pm 1.29 \mathrm{mg} / \mathrm{kg}$ ) in soil at Akwuke mine site is higher than $0.5-13.7 \mathrm{mg} / \mathrm{kg}$ in soils at Zacatecas mine, Mexico (Gonzalez and Gonzalez-Chavez, 2006). Since there were no other sources of contamination around the study area, the source of $\mathrm{Ni}$ in soil may be attributed to mine spoil from the abandoned mine.
The highest concentration of $\mathrm{Cd}(3.06 \pm 0.08 \mathrm{mg} / \mathrm{kg})$ in soil at Akwuke mine site is obtained in $0-10 \mathrm{~cm}$ valley in wet season and the value is significantly $(\mathrm{P}<0.05)$ higher than values obtained from crest $(1.73$ \pm 0.06 and $0.68 \pm 0.07 ; 0.72 \pm 0.17$ and $0.07 \pm 0.03$; $0.13 \pm 0.61$ and $0.38 \pm 0.03 \mathrm{mg} / \mathrm{kg}$ ), middle slope $(2.92 \pm 0.03$ and $0.10 \pm 0.04 ; 0.17 \pm 0.06$ and $0.01 \pm$ $0.01 ; 0.08 \pm 0.01$ and $0.02 \pm 0.01 \mathrm{mg} / \mathrm{kg}$ ) and valley $(3.06 \pm 0.08$ and $0.08 \pm 0.03 ; 0.57 \pm 0.10$ and $0.05 \pm$ $0.03 ; 0.29 \pm 0.01$ and $0.11 \pm 0.03 \mathrm{mg} / \mathrm{kg}$ ) at soil depth of $0-10,10-20$ and $20-30 \mathrm{~cm}$ (Table 2). The high concentration of $\mathrm{Cd}$ at valley may be attributed to the high mobility rate of this metal specie (Ogbonna and Okeke, 2011) in soil. The concentration of $\mathrm{Cd}(0.01 \pm$ 0.00 to $3.06 \pm 0.08 \mathrm{mg} / \mathrm{kg}$ ) in soil at Akwuke mine is higher than 0.34-2.12 mg/kg in China (Bai et al., 2008) but relatively lower than $0.4-4.76 \mathrm{mg} / \mathrm{kg}$ at the Daduk Au-Ag-Pb-Zn mine, Korea (Chon et al., 2001) and 
0.3-3.3 $\mathrm{mg} / \mathrm{kg}$ at Zacatecas mine, Mexico (Gonzalez and Gonzalez-Chavez, 2006). In this study, there was no significance difference $(\mathrm{P}>0.05)$ in the values for
As both at the coal mine site and control site. This simply infer that coal substances in Akwuke coal mine has very low content of As.

\begin{tabular}{lllllllll}
\multicolumn{7}{c}{ Table 4: Allowable limits of heavy metal concentrations in soil (mg/kg) by various countries } \\
\cline { 2 - 8 } $\begin{array}{l}\text { Heavy } \\
\text { metals }\end{array}$ & $\begin{array}{l}\text { Levels obtained } \\
\text { in this study }\end{array}$ & Austria & Germany & France & Netherlands & Sweden & UK \\
\hline $\mathrm{Cd}$ & $0.01-3.06$ & $1-2$ & 1 & 2 & 0.5 & 0.4 & 3 \\
$\mathrm{Ni}$ & $4.15-79.00$ & $50-70$ & 50 & 50 & 15 & 30 & 75 \\
$\mathrm{~Pb}$ & $6.11-81.60$ & 100 & 70 & 100 & 40 & 40 & 300 \\
$\mathrm{Fe}$ & $186.0-522.0$ & $\mathrm{NA}$ & $\mathrm{NA}$ & $\mathrm{NA}$ & $\mathrm{NA}$ & $\mathrm{NA}$ & NA \\
$\mathrm{As}$ & $0.001-0.003$ & $\mathrm{NA}$ & $\mathrm{NA}$ & $\mathrm{NA}$ & $\mathrm{NA}$ & $\mathrm{NA}$ & NA \\
\hline
\end{tabular}

Source: ECDGE $\overline{(2001) ; N A=\text { not available }}$

Soil is said to be contaminated if the concentrations of an element in soils were two-to-three times greater than the average background level (Logan and Miller, 1983). Consequently, soils at the mined site is considered to be contaminated based on the observation that $\mathrm{Fe}, \mathrm{Pb}, \mathrm{Ni}$ and $\mathrm{Cd}$ concentrations in all the background (control) soil samples are significantly lower compared to their corresponding values in Akwuke mined site. Similarly, the concentrations of $\mathrm{Cd}$ and $\mathrm{Ni}$ obtained in this study is higher than the allowable limits of these metals $(\mathrm{Cd}$ and Ni) in Austria, Germany, France, Netherlands, Sweden, and United Kingdom (Table 4). At mined site, higher concentrations of metals in soil occurred mostly at 20-30 cm (Tables 2) and this may be attributed to the leaching process and low content of organic matter on surface soil. Heavy metals are complexed by organic matter; but the low content of organic matter on surface soils vis-à-vis low soil $\mathrm{pH}$ might have enhanced the leaching of these metals into the sub-soil in wet season. Similarly, the concentrations of heavy metals in soil were generally higher at valley than crest and middle slope and this may be due to the topography of the site coupled with the leaching effect of rainfall as a result of low organic matter in soil.

Conclusion: The study indicate that coal mining activities affected the chemical characteristics of soils collected from the immediate environment of Akwuke coal mine. The flushes of acid mine drainage from the coal mine made the soil more acidic. It also increased the level of heavy metals in soil at the mine site but decimated the level of macronutrient in soil. The level of heavy metals in soils is high, thus, there is need to carry out remediation to decontaminate metals in soil.

\section{REFERENCES}

Adie, GU; Etim, EU (2012). Assessment of toxic heavy metal loading in topsoil samples within the vicinity of a limestone quarry in South Western Nigeria. Afr. J. Environ. Sci. Technol. 6(8): 322330 .
Akinbami, JFK; Ilori, MO; Oyebisi, TO; Akinwumi, IO; Adeoti, O (2001). Biogas energy use in Nigeria: current status, future prospects and policy implications. Renew. Sust. Energy Rev. 5(1): 97-112.

Aremu, MO; Atolaiye, BO; Labaran, L (2010). Environmental implication of metal concentrations in soil, plant foods and pond in area around the derelict Udege mines of Nasarawa State, Nigeria. Bull. Chem. Soc. Ethiop. 24(3): 351-360.

Bai, J; Cui, B; Wang, Q; Gao, H; Ding, Q (2008). Assessment of heavy metal contamination of roadside soils in Southwest China. Stoch. Environ. Res. Risk Assess. 23(3): 341-347.

Chen, TB; Zheng, YM; Chen, H; Zheng, GD (2004). Background concentrations of soil heavy metals in Beijing. Chinese J. Environ. Sci. 25(1): 117122.

Chon, H; Lee, CG; Jung, MC (2001). Heavy metal contamination in the vicinity of the Daduk AuAg-Pb-Zn mine in Korea. Appl. Geochem. 16(11): 1377-1386.

Derome, J; Nieminen, $\mathrm{T}$ (1998). Metal and macronutrient fluxes in heavy-metal polluted scots pine ecosystems in SW Finland. Environ. Pollut. 103(2-3): 219-228.

European Commission Director General Environment, ECDGE (2001). Heavy Metals and Organic Compounds from Wastes Used as Organic Fertilizers. Final Rep., July. WPA Consulting Engineers Inc. Ref. Nr. TEND/AML/2001/07/20, http://ec.europa.eu/environment/waste/compost/p df/hm_finalreport.pdf. p. 74. 
Fagbote, EO; Olanipekun, EO (2010). Evaluation of the Status of Heavy Metal Pollution of Soil and Plant (Chromolaena odorata) of Agbabu Bitumen Deposit Area, Nigeria. Am-Eur. J. Sci. Res. 5 (4): 241-248.

Fazekašová, D; Fazekaš, J; Hronec, O; Horňak, M (2018). Magnesium Contamination in Soil at a Magnesite Mining Area of Jelšava-Lubeník (Slovakia). 1st International Conference on Advances in Environmental Engineering: Earth Environ. Sci. 92: 1-5.

Gabriella, MG; Anton, A (2005). Phytoremediation study; factors influencing heavy metal uptake of plants. Acta Biol.. 49(1-2): 69-70.

Giachetti, G; Sebastiani, L (2006). Metal accumulation in poplar plant grown with industrial waste. Chemos. 64(3): 446-454.

Gonzalez, RC; Gonzalez-Chavez, MCA (2006). Metal accumulation in wild plants surrounding mining waste. Environ. Pollut. 144(1): 84-92.

Logan, TJ; Miller, RH (1983). Background levels of heavy metals in Ohio farm soil. Res. Circ. 275: 3 -15 .

Mahboob, AJ (2001). Heavy metal contamination of plants and soil in Itagunmodi gold deposit area of Osun State, Nigeria. Paper presented at the $27^{\text {th }}$ Annual Conference of Soil Science Society of Nigeria; Nov $18-22^{\text {nd }}, 2001$, Proceedings, $p$ p. 271-232.

Nelson, DW; Sommers, LE (1972). Determination of total nitrogen in plant material. Agron. J. 65(1): 109-112.

Nelson, DW; Sommers, LE (1982). Total carbon, organic carbon and organic matter. In: Page AL; Miller RH; Keeney DR (ed). Methods of soil analysis Part 2 Chemical and Microbiological Properties. American Society of Agronomy, Madison, p. 579.

Ogbonna, PC; Anigor, TO; Teixeira da Silva, JA (2012). Bioaccumulation of nutrients and heavy metals in plants at a coal mine. Terr. Aquat. Environ. Toxicol. 6(2): 127-131.

Ogbonna, PC; Emeh, R; Teixeira da Silva, JA (2011). Heavy metal concentration in soil and woody plants in a quarry. Toxicol. Environ. Chem. 93(5): 895-903.
Ogbonna, PC; Okeke, V (2011). Heavy metal level of soil and gmelina plantation in Umuahia, Nigeria. Terr. Aquat. Environ. Toxicol. 5(1): 31-34.

Ogbonna, PC; Okezie, N (2011). Heavy metal and macronutrient content of roadside soil and vegetation in Umuahia, Nigeria. Terr. Aquat. Environ. Toxicol. 5(1): 35-39.

Orimoloye, JR (2011). Characterisation and evaluation of selected soils of southern Nigeria for rubber (Hevea brasilienesis Muel. Arg) cultivation. Unpublished Ph.D thesis, Nigeria; University of Ibadan.

Oyedele, DJ; Gasu, MB; Awotoye, OO (2008). Changes in soil properties and plant uptake of heavy metals on selected municipal solid waste dump sites in Ile-Ife, Nigeria. Afr. J. Environ. Sci. Technol. 3(5): 107-115.

Pokethitiyook, P; Homyoga, K; Kruatrachue, M; Chaiyarat, R; Ngernsansaruayc, C (2008). Spatial and seasonal variations in lead content of plants colonizing the Bo Ngam lead mine, Thailand. ScienceAsia, 34(2): 169-178.

Sharidah, MMA (1999). Heavy metals in mangrove sediments of the United Arab Emirates shoreline (Arabian Gulf). Wat. Air Soil Pollut, 116: 523 534.

Walkley, A; Black, IA (1934). An examination of the Detgareff method for determining soil organic carbon, chronic titration method. Soil Sci. 37: 2 38.

Weis, JS; Weis, P (2004). Metal uptake, transport, and release by wetland plants: Implications for phytoremediation and restoration. Environ. Int. 30(5): 685-700.

Zocche, JJ; Rohr, P; Damiani, AP; Leffa, DD; Martins, MC; Zocche1, CM; Teixeira, KO; Borges, GD; De Jesus, MM; Dos Santos, CFI; Dias, JF; De Andrade, VM (2017). Elemental composition of vegetables cultivated over coalmining waste. An Acad Bras Cienc. 89(3): 23832398. 